\title{
Effects of Irrigation Regime and Nitrogen Level on Yield and Yield Attributes of Summer Maize (Zea mays L.)
}

\author{
A. Laxmi Prasanna ${ }^{1 *}$, Monotosh Das Bairagya ${ }^{2}$, T. Madhuri Devi ${ }^{1}$ and \\ Aftabuz Uz Zaman ${ }^{1}$ \\ ${ }^{1}$ Department of Agronomy, Faculty of Agriculture, MSSSoA, CUTM, Parlakhemundi, \\ Odisha, India \\ ${ }^{2}$ Department of Agronomy, Faculty of Agriculture, IAS, SOA, Bhubaneswar, Odisha, India \\ *Corresponding author
}

\section{Keywords \\ Maize, \\ Zea mays L. \\ Irrigation regime and nitrogen level \\ Article Info \\ Accepted: \\ 07 June 2019 \\ Available Online: \\ 10 July 2019}

\section{A B S T R A C T}

\section{Introduction}

Maize is the third most important food crop of the world and India after rice and wheat. Maize is called as 'miracle crop' due to high genetic yield potential than other cereal crops and also known as 'queen of cereals'. In India, maize is the most important food crop next to rice and wheat. Since 1950, the area, production and productivity of maize have increased more than 3.4, 12 and 4.5 times from $3.2 \mathrm{~m}$ ha, $1.7 \mathrm{~m} \mathrm{t}$ and $547 \mathrm{~kg} / \mathrm{ha}$ to current level of $8.17 \mathrm{~m}$ ha, $19.33 \mathrm{~m} \mathrm{t}$ and 2414 $\mathrm{kg} / \mathrm{ha}$, respectively due to increase in maize demand for diversified uses. Maize could be grown in wide ranges of soils and climate 
throughout the year. Maize is cultivated for grain as well as fodder purpose, and more recently used for fuel purpose. It is a rich source of raw material for industry where it is being extensively used for the preparation of by-products like corn starch, corn oil, dextrose, corn syrup, corn flakes, cosmetics, wax, alcohol and tanning material for leather industry (Khan et al., 2008). Maize is gaining importance in India due to its versatile characteristics of suitability and adaptability to various agro-climates. Maize is the most efficient coarse cereal crop and less susceptible to environmental hazards and cost of production per $\mathrm{kg}$ of grain is less compared to other cereals, which lead to drawing the attention of the farmers of Andhra Pradesh and India. In India, maize has been widely cultivated as a rainfed crop during kharif season but it can also be successfully grown during rabi season as yield level of maize during rabi season is considerably higher than that of kharif season (Patel et al., 2006).

Maize responds relatively better to management factors especially irrigation and nitrogen (Prasad et al., 1987). Irrigation is one of the important factors in agricultural practices. Optimal crop production is dependent on the time and amount of irrigation. The vital plant physiological processes like cell elongation, cell division, cell wall synthesis, nitrate reductase activity and photosynthesis are very sensitive to plant water status. Therefore, performance of a plant in terms of its growth and yield is mainly dependent on plant water status which can be maintained at optimum level by following an optimum irrigation schedule. Availability of optimum moisture in the soil enhances the efficiency of applied nutrients, and any reduction of soil moisture at these stages will considerably reduce the grain yield. So proper irrigation scheduling is essential for efficient use of water and crop production. Concept of IW/CPE ratio incorporates the climatic factors into consideration while scheduling the irrigation and has been found to be a reliable, economical and practical basis for scheduling irrigation. Deficit irrigation scheduling on the other hand is the practice of irrigating crops below the full water requirement. The effects of water stress on crop growth and grain yield will depend on the timing and magnitude of water stress as well as crop type, since different crops have different levels of tolerance to water stress. Nitrogen fertilizer played important role in improving soil fertility and increase in crop productivity. Besides, nitrogen is an integral component of many compounds. It also mediates the utilization of potassium, phosphorus and other elements in plants. Nitrogen is a constituent of protein, enzymes, hormones, vitamins, alkaloids and chlorophyll hence nitrogen deficit in plants leads to improper growth and development. The kernel yield of maize and the quality of kernel is also depending on nitrogen availability. Maize has maximum nitrogen use efficiency of about 50 per cent, but under poor management, its efficiency varies from 30-40 per cent (Patel et al., 2006). The optimal amount of these elements in the soils cannot be utilized efficiently if nitrogen is deficient in plants. In addition to supplying a nutrient for plant growth, $\mathrm{N}$ application could improve drought tolerance of plants to enhance yields. Water and nitrogen are two important resources for crop production. Yields in maize gave positive response with an increase in the amount of water and nitrogen applied and reaches the plateau at their optimum doses. Keeping this view in mind, a field experiment had been conducted during summer season of 2018 at Bagusala Farm (18.7783 N latitude and $84.0937 \mathrm{E}$ longitudes) of M.S. Swaminathan School of Agriculture, CUTM, Parlakhemundi, Odisha under typical humid and sub-tropical climatic conditions to know the suitable irrigation scheduling and optimum nitrogen level through organic sources for summer maize. 


\section{Materials and Methods}

A field trail was conducted during summer season of 2018 at Bagusala Farm (18.7783 N latitude and $84.0937 \mathrm{E}$ longitude) of M. S. Swaminathan School of Agriculture, CUTM, Parlakhemundi, Odisha under typical humid and sub-tropical climatic conditions to know the best irrigation scheduling and optimum nitrogen level for summer maize. Three irrigation regimes was laid out in main plot and four levels of nitrogen from organic source in sub plots, 12 treatment combinations were replicated thrice. The spacing of maize crop was $60 \times 30 \mathrm{~cm}$ and variety taken from the experiment was NHM-666. The treatment combinations include three irrigation levels $\left(\mathrm{I}_{1}, \mathrm{I}_{2}\right.$ and $\mathrm{I}_{3}$ at $0.6,0.8$ and $1.0 \mathrm{IW} / \mathrm{CPE}$ respectively) and four nitrogen levels $\left(\mathrm{N}_{1}, \mathrm{~N}_{2}\right.$, $\mathrm{N}_{3}$ and $\mathrm{N}_{4}$ at 100\%, 50\%, 25\% and $0 \%$ through organic sources respectively). The treatments were laid out using Factorial Randomised Block Design and replicated thrice with 12 treatment combinations. The experimental plot size was $5 \mathrm{~m} \times 4 \mathrm{~m}$. The biometric (plant height, LAI and dry matter) and yield and yield attributes from each treatment were taken and tabulated after statistical test.

\section{Soil data}

Data from soil and plant were taken periodically. The soil type of experimental field was sandy loam in texture with $\mathrm{pH}$ of 6.3 and EC was $0.19 \mathrm{dSm}^{-1}$. The available soil $\mathrm{N}$ was $115 \mathrm{~kg} / \mathrm{ha}$ which is low, $\mathrm{P}_{2} \mathrm{O}_{5}$ was 252 $\mathrm{kg} / \mathrm{ha}$ which is high and $\mathrm{K}_{2} \mathrm{O}$ was $541 \mathrm{~kg} / \mathrm{ha}$ which is high in range (Table 1).

\section{Meteorological parameters}

The maximum temperature during cropping season was ranged between $33.9^{\circ} \mathrm{C}$ and $41.8^{\circ} \mathrm{C}$ whereas minimum temperature ranged from $16.9^{\circ} \mathrm{C}$ to $22^{\circ} \mathrm{C}$. Total rainfall occurred during cropping season was 444.8 $\mathrm{mm}$. Average BSS from Feb to May was also shown in (Table 2).

\section{Results and Discussion}

\section{Effect on plant parameters}

In both occasions, (60 DAS and Harvest) $I_{3}$ produced highest plant height (173.6 and $269.1 \mathrm{~cm}$ respectively) followed by $\mathrm{I}_{2}(171.7$ and $259.4 \mathrm{~cm}$ respectively) and the same trend was observed in case of GGR and LAI during 60 DAS (3.14 and 2.74 respectively) and at harvest (1.83 and 0.70 respectively). At 60DAS and harvest plant height $(53.2 \mathrm{~cm}$ and $273.7 \mathrm{~cm})$, CGR (3.1 and 1.68) and LAI (2.67 and 0.77 ) found statistically highest in $\mathrm{N}_{1}$ followed by $\mathrm{N}_{2}$. Lowest plant height $(50.8 \mathrm{~cm}$ and $246.3 \mathrm{~cm})$, CGR $\left(1.64 \mathrm{~g} / \mathrm{m}^{2} /\right.$ day $)$ and LAI (2.32 and 0.52) were observed in no FYM $(0 \%$ FYM) applied for plot (Table 3). The increase in plant height in response to more number of irrigations was also reported by Adamu et al., (2014).

\section{Effect on yield and yield attributes}

Average cob weight was recorded highest in $\mathrm{I}_{3}$ (171.22 q/ha) due to more no of irrigations followed by $\mathrm{I}_{2}(162.06 \mathrm{q} / \mathrm{ha})$. Lowest cob weight was recorded in $I_{1}(152.93 \mathrm{q} / \mathrm{ha})$. It may be due to water stress. Cob girth was recorded $13.7 \mathrm{~cm}\left(\mathrm{I}_{1}\right.$ and $\left.\mathrm{I}_{2}\right)$ and $13.4\left(\mathrm{I}_{3}\right)$ respectively. Maximum Stover yield and seed yield was observed in $\mathrm{I}_{3}(141.17 \mathrm{q} / \mathrm{ha}$ and $83.78 \mathrm{q} / \mathrm{ha}$ respectively) and lowest yield had been seen in $I_{1}(134.13 \mathrm{q} / \mathrm{ha}$ and $70.69 \mathrm{q} / \mathrm{ha}$ respectively). Harvest index has been recorded as $24.61,26.37$ and 26.70 respectively in $I_{1}, I_{2}$ and $\mathrm{I}_{3}$.

Cob weight was recorded significantly highest in $\mathrm{N}_{1}(171.22 \mathrm{q} / \mathrm{ha})$ due to more applied nitrogen through FYM followed by $\mathrm{N}_{2}$ (167.59 q/ha). 
Table.1 Physico-chemical properties of experimental soil

\begin{tabular}{|c|c|c|}
\hline S. No & Properties & Value \\
\hline A & Physical properties & \\
\hline $\mathbf{1 .}$ & Sand $(\%)$ & $\mathbf{4 0 . 5 8}$ \\
\hline $\mathbf{2 .}$ & Silt $(\%)$ & $\mathbf{3 8 . 9 7}$ \\
\hline $\mathbf{3 .}$ & Clay $(\%)$ & $\mathbf{2 0 . 4 7}$ \\
\hline $\mathbf{4}$. & Textural class & Sandy loam \\
\hline B & Chemical Properties & \\
\hline $\mathbf{1 .}$ & Available nitrogen $(\mathrm{kg} / \mathrm{ha})$ & $\mathbf{1 1 5}$ \\
\hline $\mathbf{2 .}$ & Available phosphorus $(\mathrm{kg} / \mathrm{ha})$ & $\mathbf{2 5 2}$ \\
\hline $\mathbf{3 .}$ & Available potassium $(\mathrm{kg} / \mathrm{ha})$ & $\mathbf{5 4 1}$ \\
\hline $\mathbf{4 .}$ & Soil reaction $(\mathrm{Ph})$ & $\mathbf{6 . 3}$ \\
\hline $\mathbf{5 .}$ & Electrical conductivity $\left(\mathrm{dsm}{ }^{-1}\right)$ & $\mathbf{0 . 1 9}$ \\
\hline 6. & Organic carbon $(\mathbf{p p m})$ & $\mathbf{0 . 4 5}$ \\
\hline
\end{tabular}

Table.2 Meteorological observations during cropping season

\begin{tabular}{|c|c|c|c|c|c|c|c|}
\hline \multirow{2}{*}{ Month } & \multicolumn{2}{|c|}{ Temperature $\mathbf{(}^{\mathbf{0}} \mathbf{C )}$} & \multicolumn{2}{|c|}{$\begin{array}{c}\text { Relative humidity } \\
(\mathbf{\%})\end{array}$} & $\begin{array}{c}\text { Rainfall } \\
(\mathbf{m m})\end{array}$ & $\begin{array}{c}\text { ET } \\
(\mathbf{m m})\end{array}$ & $\begin{array}{c}\text { BSS } \\
(\mathbf{H r})\end{array}$ \\
\cline { 2 - 7 } & Maximum & Minimum & Morning & Afternoon & & & \\
\hline February & 33.9 & 16.9 & 90 & 36 & 0.0 & 9 & 8.8 \\
\hline March & 41.4 & 22.0 & 89 & 56 & 102.3 & 104 & 6.6 \\
\hline April & 41.8 & 20.8 & 89 & 59 & 32.8 & 127.4 & 7.2 \\
\hline May & 41.7 & 21.2 & 92 & 74 & 309.7 & 111.8 & 6.6 \\
\hline
\end{tabular}

Table.3 Effect of treatments on plant height, CGR and LAI of summer maize

\begin{tabular}{|c|c|c|c|c|c|c|}
\hline \multirow[t]{2}{*}{ Treatment } & \multicolumn{2}{|c|}{ Plant height (cm) } & \multicolumn{2}{|c|}{ CGR (g/m²/day) } & \multicolumn{2}{|c|}{ LAI } \\
\hline & $60 \mathrm{DAS}$ & Harvest & $30-60$ & $\begin{array}{c}90 \text { DAS- } \\
\text { Harvest }\end{array}$ & 60 & Harvest \\
\hline \multicolumn{7}{|c|}{ Irrigation levels } \\
\hline $\mathbf{I}_{1}$ & 167.4 & 251.2 & 3.01 & 1.62 & 2.31 & 0.54 \\
\hline $\mathbf{I}_{2}$ & 171.7 & 259.4 & 3.06 & 1.55 & 2.45 & 0.62 \\
\hline$I_{3}$ & 173.6 & 269.1 & 3.14 & 1.83 & 2.74 & 0.70 \\
\hline SEM \pm & 0.74 & 1.29 & 0.024 & 0.01 & 0.01 & 0.007 \\
\hline $\mathrm{CD}(\mathrm{p}=0.05)$ & 2.17 & 3.80 & 0.07 & 0.04 & 0.03 & 0.02 \\
\hline \multicolumn{7}{|c|}{ Nitrogen levels } \\
\hline $\mathbf{N}_{1}$ & 53.2 & 273.7 & 3.10 & 1.68 & 2.67 & 0.77 \\
\hline $\mathbf{N}_{2}$ & 52.8 & 264.8 & 3.05 & 1.61 & 2.59 & 0.67 \\
\hline $\mathbf{N}_{3}$ & 51.3 & 254.8 & 3.06 & 1.74 & 2.43 & 0.53 \\
\hline $\mathbf{N}_{4}$ & 50.8 & 246.3 & 3.07 & 1.64 & 2.32 & 0.52 \\
\hline SEM \pm & 0.29 & 1.73 & 0.03 & 0.02 & 0.16 & 0.01 \\
\hline $\mathrm{CD}(\mathrm{p}=0.05)$ & 0.87 & 5.07 & 0.09 & 0.06 & 0.04 & 0.02 \\
\hline CV\% & 5.19 & 5.99 & 9.6 & 11.7 & 5.96 & 14.4 \\
\hline
\end{tabular}


Table.4 Effect of treatments on average cob weight, cob girth, Stover yield, seed yield and harvest index of summer maize

\begin{tabular}{|c|c|c|c|c|c|}
\hline Treatment & $\begin{array}{l}\text { Average cob } \\
\text { weight (q/ha) }\end{array}$ & $\begin{array}{c}\text { Cob girth } \\
\text { (cm) }\end{array}$ & $\begin{array}{c}\text { Stover } \\
\text { yield(q/ha) }\end{array}$ & $\begin{array}{c}\text { Seed } \\
\text { Yield(q/ha) }\end{array}$ & $\begin{array}{c}\text { Harvest } \\
\text { index }\end{array}$ \\
\hline \multicolumn{6}{|c|}{ Irrigation } \\
\hline $\mathbf{I}_{\mathbf{1}}$ & 152.93 & 13.70 & 134.13 & 70.69 & 24.61 \\
\hline $\mathbf{I}_{2}$ & 162.06 & 13.70 & 140.93 & 79.90 & 26.37 \\
\hline $\mathbf{I}_{\mathbf{3}}$ & 171.22 & 13.43 & 141.17 & 83.78 & 26.70 \\
\hline SEM \pm & 0.80 & 0.059 & 0.585 & 0.38 & 0.13 \\
\hline $\mathrm{CD}(\mathrm{p}=0.05)$ & 2.37 & 0.175 & 1.71 & 1.11 & 0.38 \\
\hline \multicolumn{6}{|c|}{ Nitrogen } \\
\hline $\mathbf{N}_{1}$ & 177.72 & 13.58 & 152.43 & 85.50 & 25.88 \\
\hline $\mathbf{N}_{2}$ & 167.59 & 13.59 & 140.53 & 79.58 & 25.80 \\
\hline $\mathbf{N}_{3}$ & 157.83 & 13.53 & 133.91 & 75.03 & 25.69 \\
\hline $\mathbf{N}_{4}$ & 147.81 & 13.74 & 128.09 & 72.39 & 26.20 \\
\hline SEM \pm & 1.07 & 0.079 & 0.78 & 0.50 & 0.17 \\
\hline $\mathrm{CD}(\mathrm{p}=0.05)$ & 3.16 & 0.023 & 2.29 & 1.49 & 0.50 \\
\hline CV\% & 5.9 & 5.2 & 5.06 & 5.85 & 6.02 \\
\hline
\end{tabular}

Table.5 Interaction effect of treatments on grain yield, Stover yield, harvest index and water use efficiency of summer maize

\begin{tabular}{|c|c|c|c|c|}
\hline Treatment & $\begin{array}{c}\text { Grain yield } \\
\text { (kg/ha) }\end{array}$ & $\begin{array}{c}\text { Stover yield } \\
(\mathbf{q} / \mathbf{h a})\end{array}$ & Harvest index & $\begin{array}{c}\mathbf{W U E} \\
(\mathbf{k g} / \mathbf{h a} / \mathbf{m m})\end{array}$ \\
\hline $\mathbf{I}_{\mathbf{1}} \mathbf{N}_{\mathbf{1}}$ & 7818.3 & 146.28 & 24.96 & 32.31 \\
\hline $\mathbf{I}_{\mathbf{1}} \mathbf{N}_{\mathbf{2}}$ & 7169.7 & 133.77 & 24.74 & 29.63 \\
\hline $\mathbf{I}_{\mathbf{1}} \mathbf{N}_{\mathbf{3}}$ & 6839.0 & 130.88 & 24.21 & 27.90 \\
\hline $\mathbf{I}_{\mathbf{1}} \mathbf{N}_{\mathbf{4}}$ & 6451.3 & 125.59 & 24.52 & 26.66 \\
\hline $\mathbf{I}_{\mathbf{2}} \mathbf{N}_{\mathbf{1}}$ & 8758.3 & 153.6 & 26.51 & 26.70 \\
\hline $\mathbf{I}_{\mathbf{2}} \mathbf{N}_{\mathbf{2}}$ & 8249.7 & 145.29 & 26.54 & 25.27 \\
\hline $\mathbf{I}_{\mathbf{2}} \mathbf{N}_{\mathbf{3}}$ & 7605.3 & 134.21 & 26.25 & 24.02 \\
\hline $\mathbf{I}_{\mathbf{2}} \mathbf{N}_{\mathbf{4}}$ & 7348.0 & 130.61 & 26.15 & 22.77 \\
\hline $\mathbf{I}_{\mathbf{3}} \mathbf{N}_{\mathbf{1}}$ & 9075.0 & 157.42 & 26.16 & 22.50 \\
\hline $\mathbf{I}_{\mathbf{3}} \mathbf{N}_{\mathbf{2}}$ & 8456.7 & 142.50 & 26.11 & 20.97 \\
\hline $\mathbf{I}_{\mathbf{3}} \mathbf{N}_{\mathbf{3}}$ & 8064.7 & 136.66 & 26.60 & 20.00 \\
\hline $\mathbf{I}_{\mathbf{3}} \mathbf{N}_{\mathbf{4}}$ & 7918.3 & 128.08 & 27.91 & 19.63 \\
\hline $\mathbf{S E M} \mathbf{M}$ & 1.52 & 2.34 & 0.52 & \\
\hline $\mathbf{C D}(\mathbf{p}=\mathbf{0 . 0 5})$ & 4.47 & 6.87 & 1.52 & \\
\hline $\mathbf{C V}$ \% & 5.85 & 5.06 & 6.02 & \\
\hline & & & & \\
\hline
\end{tabular}


Table.6 Effect of treatments on economics of summer crop

\begin{tabular}{|c|c|c|c|c|c|}
\hline Treatment & $\begin{array}{c}\text { Grain } \\
\text { yield(q/ha) }\end{array}$ & $\begin{array}{c}\text { Cost of } \\
\text { cultivation(Rs/ha) }\end{array}$ & $\begin{array}{c}\text { Gross } \\
\text { returns(Rs/ha) }\end{array}$ & $\begin{array}{c}\text { Net returns } \\
\text { (Rs/ha) }\end{array}$ & $\begin{array}{c}\text { B:C } \\
\text { ratio }\end{array}$ \\
\hline $\mathbf{I}_{\mathbf{1}} \mathbf{N}_{\mathbf{1}}$ & 78.18 & 35475 & 93820.00 & 58345.00 & 2.64 \\
\hline $\mathbf{I}_{\mathbf{1}} \mathbf{N}_{\mathbf{2}}$ & 71.69 & 31625 & 86036.00 & 54411.00 & 2.72 \\
\hline $\mathbf{I}_{\mathbf{1}} \mathbf{N}_{\mathbf{3}}$ & 68.39 & 29700 & 82068.00 & 52368.00 & 2.76 \\
\hline $\mathbf{I}_{\mathbf{1}} \mathbf{N}_{\mathbf{4}}$ & 64.51 & 21175 & 77416.00 & 56241.00 & 3.66 \\
\hline $\mathbf{I}_{\mathbf{2}} \mathbf{N}_{\mathbf{1}}$ & 87.58 & 36355 & 105100.00 & 68745.00 & 2.89 \\
\hline $\mathbf{I}_{\mathbf{2}} \mathbf{N}_{\mathbf{2}}$ & 82.49 & 32505 & 98996.00 & 66491.00 & 3.05 \\
\hline $\mathbf{I}_{\mathbf{2}} \mathbf{N}_{\mathbf{3}}$ & 76.05 & 30580 & 91264.00 & 60684.00 & 2.98 \\
\hline $\mathbf{I}_{\mathbf{2}} \mathbf{N}_{\mathbf{4}}$ & 73.48 & 22055 & 88176.00 & 66121.00 & 4.00 \\
\hline $\mathbf{I}_{\mathbf{3}} \mathbf{N}_{\mathbf{1}}$ & 90.75 & 37125 & 108900.00 & 71775.00 & 2.93 \\
\hline $\mathbf{I}_{\mathbf{3}} \mathbf{N}_{\mathbf{2}}$ & 84.56 & 33275 & 101480.00 & 68205.00 & 3.05 \\
\hline $\mathbf{I}_{\mathbf{3}} \mathbf{N}_{\mathbf{3}}$ & 80.64 & 31350 & 96776.00 & 65426.00 & 3.09 \\
\hline $\mathbf{I}_{\mathbf{3}} \mathbf{N}_{\mathbf{4}}$ & 79.1 & 29700 & 95020.00 & 65320.00 & 3.20 \\
\hline
\end{tabular}

Lowest plant cob weight was recorded in $\mathrm{N}_{4}$ (147.81 q/ha). It may be due to no application of FYM. Cob girth was recorded in $\mathrm{N}_{1}, \mathrm{~N}_{2}, \mathrm{~N}_{3}$ and $\mathrm{N}_{4}$ as 13.58, 13.59, 13.53 and $13.74 \mathrm{~cm}$ respectively. Maximum Stover yield and seed yield was observed in $\mathrm{N}_{1}$ (152.43q/ha and $85.50 \mathrm{q} /$ ha respectively) and lowest yield had been seen in $\mathrm{N}_{4}$ (128.09 q/ha and 72.39 q/ha respectively). Highest harvest index has been recorded as 26.20 in $\mathrm{N}_{4}$ (Table 4). Higher yield at increased levels of nitrogen might be owing to better nutrient uptake leading to greater drymatter production and higher photosynthetic rate and increased translocation of photosynthates from source to sink. Similar results were reported by Aulakh et al., (2013) and Mahesh et al., (2016).

Interaction on Grain Yield, Stover yield, Harvest Index and Water use efficiency

In interaction of irrigation regimes and nitrogen levels, highest grain yield was recorded in $\mathrm{I}_{3} \mathrm{~N}_{1}(9075.0 \mathrm{~kg} / \mathrm{ha})$ by providing more no of irrigations and high nitrogen followed by $\mathrm{I}_{2} \mathrm{~N}_{1}(8758.3 \mathrm{~kg} / \mathrm{ha})$.Lowest grain yield was recorded in $\mathrm{I}_{1} \mathrm{~N}_{4}(6451.3 \mathrm{~kg} / \mathrm{ha})$ for the moisture and nutrient (nitrogen) stress.
Maximum Stover yield and seed yield observed in $\mathrm{I}_{3} \mathrm{~N}_{1}$ (157.42 and $90.75 \mathrm{q} / \mathrm{ha}$ ) and lowest yield had been seen in $\mathrm{I}_{1} \mathrm{~N}_{4}(125.59$ and 64.51 respectively) in all levels of ' $\mathrm{N}$ '. Highest water use efficiency computed in $\mathrm{I}_{1}$ and it ranged from 32.3 to $26.6 \mathrm{~kg} / \mathrm{ha} / \mathrm{mm}$. Similar results were reported by Dutta et al., (2015) (Table 5).

\section{Economics of crop}

Highest gross return (Rs/ha 108900/-) and net return (Rs/ha 71775/-) obtained in $\mathrm{I}_{1} \mathrm{~N}_{1}$ whereas least gross return and net return calculated in $\mathrm{I}_{1} \mathrm{~N}_{3}$ (Rs/ha 82068/- and Rs/ha 52368/- respectively) (Table 6). Benefit cost ratio (4.0) was calculated highest in irrigation at IW/CPE is 0.8 with no application of FYM.

Irrigation of IW/CPE at 0.8 saves water without any significant reduction of green cob as well as seed yield. Application of FYM @ 10t/ha produced highest grain yield.

\section{References}

Adamu, C., Kumar, B.N.A., Rajkumara, S., Patil, B.R., Patil, H.Y and Kuligod, 
V.B. 2014. Physiological response, molecular analysis and water use efficiency of maize (Zea mays L.) hybrids grown under various irrigation regimes. African Journal of Biotechnology. 13(29): 2966-2976.

Aulakh, G.S., Vashist, K.K and Mahal, S.S. 2013. Effect of different irrigation regimes and nitrogen levels on growth parameters and yield of late kharif sown maize (Zea mays L.). Crop Research. 45(1, 2 \& 3): 96-105.

Dutta, D., Mudi, D.D and Thentu, T.L. 2015. Effect of irrigation levels and planting geometry on growth, cob yield and water use efficiency of baby corn (Zea mays L.). Journal of Crop and Weed. 11(2): 105-110.

Khan, H.Z., Malik, M.A and Saleem, M.F. 2008. Effect of rate and source of organic material on the production potential of spring maize (Zea mays L.).
Pakistan Journal of Agricultural Sciences. 45: 40-43

Mahesh, N., Rani, P. L., Sreenivas, G and Madhavi, A. 2016. Performance of kharif maize under different plant populations and nitrogen levels in southern Telangana. International Journal of Farm Sciences. 6(1): 205213.

Patel, J.B., Patel, V.J and Patel, J.R. 2006. Influence of different methods of irrigation and nitrogen levels on crop growth rate and yield of maize (Zea mays L.). Indian Journal of Crop Sciences. 1 (1\&2): 175-177.

Prasad, U.K., Thakur, H.C., Pandey, S.S., Pandey, R.D and Sharma, N.N. 1987. Effect of irrigation and nitrogen on winter maize in calcareous saline alkali soils. Indian Journal of Agronomy. 32: 217-210.

\section{How to cite this article:}

Laxmi Prasanna, A., Monotosh Das Bairagya, T. Madhuri Devi and Aftabuz Uz Zaman. 2019. Effects of Irrigation Regime and Nitrogen Level on Yield and Yield Attributes of Summer Maize (Zea mays L.). Int.J.Curr.Microbiol.App.Sci. 8(07): 727-733. doi: https://doi.org/10.20546/ijcmas.2019.807.088 